\title{
RANCANG BANGUN ALAT UJI KEAUSAN (TRIBOMETER) DENGAN PENGGERAK MOTOR TIPE XD - 135
}

\author{
PUTRA PARTAMA \\ Program Studi Teknik Mesin, Fakultas Teknik, Universitas Muhammadiyah Riau \\ Jalan Tuanku Tambusai Ujung, Kecamatan Tampan, Kelurahan Delima, Kota Pekanbaru, Riau 28291 \\ E-mail:pp305402@gmail.com
}

\begin{abstract}
Every object that moves and comes in contact with one another must experience friction. Friction or commonly referred to as friction is a force that restricts the sliding or rolling motion of an object against another object. The design and manufacturing stage of the tibometer test device, which uses a motor type $X D-135$ as a driving force with a maximum load of 98N, knows the dimensions of the components (tribometer) to be made. The design process is carried out by determining the specifications of the equipment to be made, making the design concept of the wear test equipment, making the design of the wear test equipment, the manufacturing process of the wear test equipment. The design and manufacture results in a tibometer test device with specifications of rotation speed $212.12 \mathrm{rpm}$, linear speed $448.9 \mathrm{~mm} / \mathrm{s}$, maximum normal load $98 \mathrm{~N}$, normal force $49 \mathrm{~N}$, stroke length $70 \mathrm{~mm}$.
\end{abstract}

Keywords: Friction, tribometer, wear

\section{Abstrak}

Setiap benda yang bergerak dan bersentuhan antara satu dengan yang lainnya pasti mengalami gesekan. Gesekan atau biasa disebut dengan friksi adalah gaya yang menahan gerakan sliding atau rolling suatu benda terhadap benda lainnya. Tahap perancangan dan pembuatan alat uji keusan (tibometer), yang menggunakan motor tipe XD - 135 sebagai penggerak dengan pembebanan maksimal 98N, mengetahui dimensi dari komponen-komponen (tribometer) yang akan dibuat. Proses perancangan dialakukan adalah penentuan spesifikasi alat yang akan dibuat, membuat konsep rancangan alat uji keausan, membuat desain alat uji keusan, proses manufaktur alat uji keusan. Hasil perancangan dan pembuatan menghasilkan alat uji keusan (tibometer) dengan spesifikasi rotation speed 212,12 rpm, linier speed 448,9 mm/s, maximum normal load $98 \mathrm{~N}$, normal force $49 \mathrm{~N}$, stroke length $70 \mathrm{~mm}$.

Kata kunci : Gesekan, tribometer, keausan

\section{Pendahuluan}

Setiap benda yang bergerak dan bersentuhan antara satu dengan yang lainnya pasti mengalami gesekan. Gesekan atau biasa disebut dengan friksi adalah gaya yang menahan gerakan sliding atau rolling suatu benda terhadap benda lainnya [6].

Penyebab utama gesekan antara dua benda kelihatanya adalah gaya tarik (adhesi) daerah kontak dari permukaan permukaan yang secara mikroskopik tidak beraturan, jika diperbesar permukaannya menyerupai bukit dan lembah [6].

Gesekan yang terjadi secara terus-menerus dapat menyebabkan terjadinya keausan atau hilangnya partikel suatu benda. Keausan terjadi apabila dua buah benda yang saling menekan dan saling bergesekan. Keausan yang lebih besar terjadi pada bahan yang lebih lunak [2].

Faktor-faktor yang mempengaruhi keausan adalah kecepatan, tekanan, kekasaran permukaan dan kekerasan bahan. Semakin besar kecepatan relative benda yang bergesekan, maka material semakin mudah aus. Demikian pula semakin besar tekanan pada permukaan benda yang berkontak, material akan cepat aus, begitu pula sebaliknya [5].

Keausan yang mengakibatkan berkurangnya material-material pada benda akan menyebabkan kerusakan pada benda tersebut. Untuk mengatasi adanya keausan biasanya diberikan pelumas. 
Dalam pengembangan ilmu tribologi terutama untuk keperluan penelitian, sangat dibutuhkan alat-alat pengujian khususnya alat uji gesekan dan keausan.

Namun di Indonesia alat uji tribologi masih jarang sekali. Penelitian yang sudah dilakukan sebelumnya telah membuat alat uji gesekan dan keausan atau tribometer tipe pin-on-disc dengan gerakan 1 arah saja (Kun Muhammad W, 2015) [7].

Pernah didesain juga untuk 2 arah dengan mekanisme crankshaft namun menimbulkan osilasi yang tinggi sehingga menyebabkan hasil pengujian yang kurang presisi (Petrus Londa, 2013). Oleh karena itu pada tugas akhir ini dirancang alat uji keausan tribometer untuk 2 arah yang digerakkan dengan motor tipe XD - 135, dimana nanti hasilnya diharapkan bisa mengurangi osilasi yang terjadi dan gerakan stabil sehingga didapatkan hasil pengujian yang lebih presisi. Dari permasalahan diatas penulis tertarik mengambil topik ini sebagai tugas akhir dengan judul "Rancang Bangun Alat Uji Keausan (Tribometer) Dengan Penggerak Motor Tipe Xd $-135 "$ ".

Merancang adalah merumuskan rencana untuk kepuasan kebutuhan yang ditentukan atau untuk memecahkan sebuah masalah. Jika rencana menghasilkan penciptaan sesuatu yang memiliki realitas fisik, maka produk tersebut harus fungsional, aman, andal, kompetitif, dapat digunakan, dapat dipabrikasi, dan dipasarkan (Budynas, 2011) [8].

Tribologi adalah ilmu dan teknologi yang yang mempelajari peristiwa interaksi dua permukaan yang bergerak relatif satu terhadap fenomena gesekan,pelumasan dan keausan. Secara umum tribometer adalah alat yang digunakan untukmmengukur gesekan dan keausan antara dua permukaan [7].

Ada beberapa desain pada tribometer, yang sering digunakan adalah desain dengan permukaan datar atau bulat yang bergerak berulangulang dan bergesekan dengan permukaan lain. Sebuah material ditempatkan tepat pada bagian yang bergerak selama pengujian. Pengujian tersebut digunakan untuk mengukur keausan pada bahan dan digunakan untuk menentukan kekuatan dan panjang umur [7].

Gaya gesek adalah gaya yang berarah melawan gerak benda atau arah kecenderungan benda untuk bergerak. Gaya gesek muncul apabila dua buah benda bersentuhan. Benda-benda yang dimaksud di sini tidak harus berbentuk padat, melainkan dapat pula berbentuk cair ataupun gas [4].
Gaya gesek antara dua buah benda padat misalnya adalah gaya gesek statis dan kinetis, sedangkan gaya antara benda padat dan cairan serta gas adalah gaya Stokes [4].

Keausan yaitu sebagai hilangnya bagian dari permukaan yang saling berinteraksi yang terjadi sebagai hasil gerak relatif pada permukaan. Keausan yang terjadi pada suatu material disebabkan oleh adanya beberapa mekanisme yang berbeda dan terbentuk oleh beberapa parameter yang bervariasimeliputi bahan, lingkungan, kondisi operasi, dan geometri permukaan benda yang terjadi keausan [3].

Mekanisme keausan dikelompokkan menjadi dua kelompok, yaitu keausan yang penyebabnya didominasi oleh perilaku mekanis dari bahan dan keausan yang penyebabnya didominasi oleh perilaku kimia dari bahan [1].

Tujuan dari penelitian ini adalah:

1. Merancang alat uji keausan (Tibometer).

2. Membuat alat uji keausan (Tribometer).

\section{Methodologi}

Penelitian ini dilakukan melalui beberapa langkah kerja. Awalnya menyiapkan \& menentukan alat dan bahan, proses pengukuran, pemotongan dan pengeboran material, proses pengelasan rangka alat uji keausan, proses pengeboran rangka alat uji keusan sesuai tempat yang telah ditetapkan, proses pemasangan motor, puli, sabuk-v, bearing block, poros dan disc, proses pemasangan motor, puli, sabuk-v, bearing block, proses pemasanganconnecting rod, proses pemasangan ragum, Proses pengecatan dan pemasangan kelistrikan alat uji keausan. Dalam tahap ini, prosedur yang akan di lakukan ialah menentukan dan menyiapkan alat dan bahan yang diperlukan dalam penelitian.

A. Alat

1. Gerinda

2. Mesin las

3. Bor

4. Alat ukur

5. Perkakas atau kunci - kunci yang di perlukan

B. Bahan

1. Besi plat $5 \mathrm{~mm}$ dan $8 \mathrm{~mm}$.

2. Besi hollow $2,5 \times 2,5 \mathrm{~mm}$ tebal $1,2 \mathrm{~mm}$.

3. Elektroda 2,6mm .

4. Besi strip $4 \mathrm{~mm} \times 40 \mathrm{~mm} \times 30 \mathrm{~cm}$ Ragum 3 inch. 
5. Motor Ac tipe M921-10/YYG60A.

6. Puli 2" dan 12".

7. Pillow blocks bearing P205 2 buah.

8. Poros 1" panjang $180 \mathrm{~mm}$.

9. Sabuk-V A52.

10. Bearing 63004 buah

11. As roda $10 \mathrm{~mm} \times 2103$ buah, dan as roda $12 \mathrm{~mm} \times 240 \mathrm{~mm} 2$ buah.

12. Bushing $10 \mathrm{~mm} \times 60 \mathrm{~mm} 3$ buah dan $12 \mathrm{~mm}$ x $60 \mathrm{~mm} 2$ buah.

13. Ragum 3".

14. Baut dan mur $14 \mathrm{~mm}$ x $50 \mathrm{~mm}$ 11 buah dan $12 \mathrm{~mm} \times 30 \mathrm{~mm} 2$ buah.

15. Steker, kabel serabut $2 \times 1,5$ $2 \mathrm{~m}$,

16. Dimmer $2000 \mathrm{~W} 220 \mathrm{~V}$ Ac.

17. Rpm tachometer $12 \mathrm{~V}$.

18. Cat warna biru.

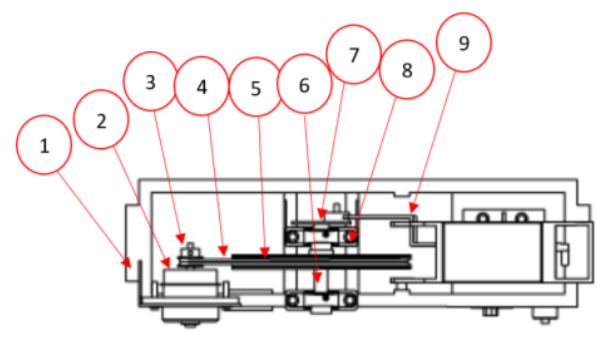

Gambar 3.3. Sketsa alat uji keusan tampak atas

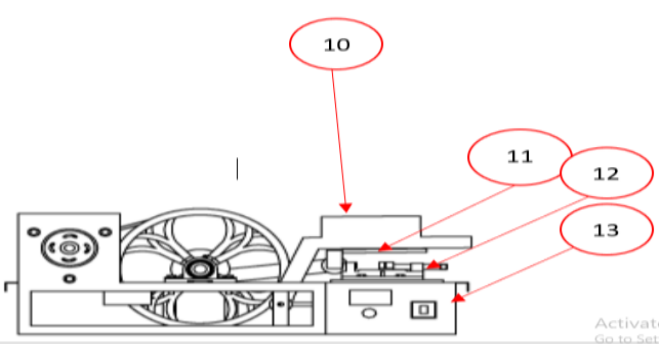

Gambar 3.4. Sketsa alat uji keausan tampak samping Berikut penjelasan tentang nama-nama bagian dan fungsi komponen alat uji keausan (tribometer).

Tabel 3.2. Nama - nama bagian dan fungsi komponen

\begin{tabular}{|c|l|l|}
\hline No & \multicolumn{1}{|c|}{ Nama } & \multicolumn{1}{c|}{ Fungsi } \\
\hline 1. & Rangka & $\begin{array}{l}\text { Sebagai penyokong } \\
\text { dari bagian-bagian } \\
\text { alat uji. }\end{array}$ \\
\hline 2. & Motor & $\begin{array}{l}\text { Sebagai penggerak } \\
\text { media penggesek } \\
\text { yang disambung }\end{array}$ \\
\hline
\end{tabular}

\begin{tabular}{|c|c|c|}
\hline & & $\begin{array}{l}\text { dari poros engkol } \\
\text { dan diteruskan } \\
\text { melalui connecting } \\
\text { rod. }\end{array}$ \\
\hline 3. & Puli motor & $\begin{array}{l}\text { Penghubung } \\
\text { mekanis atau } \\
\text { penghantar daya. }\end{array}$ \\
\hline 4. & Sabuk-V & $\begin{array}{l}\text { Transmisi } \\
\text { penghubung puli. }\end{array}$ \\
\hline 5. & Puli penggerak & $\begin{array}{l}\text { Sebagai penguhung } \\
\text { gerakan ke poros. }\end{array}$ \\
\hline 6. & Poros & $\begin{array}{l}\text { Meneruskan daya } \\
\text { dari sumber daya ke } \\
\text { disc. }\end{array}$ \\
\hline 7. & Disc & $\begin{array}{l}\text { Meneruskan daya } \\
\text { dari sumber daya } \\
\text { dan mengubah gerak } \\
\text { melingkar menjadi } \\
\text { Gerak linear. }\end{array}$ \\
\hline 8. & $\begin{array}{l}\text { Pillow blocks } \\
\text { bearing }\end{array}$ & $\begin{array}{l}\text { Alas pendukung } \\
\text { kerja poros. }\end{array}$ \\
\hline 9. & Connecting rod & $\begin{array}{l}\text { Berfungsi untuk } \\
\text { penghubung poros } \\
\text { engkol dan benda } \\
\text { penggesek dan juga } \\
\text { mengubah gerak } \\
\text { melingkar menjadi } \\
\text { gerak linear. }\end{array}$ \\
\hline 10. & $\begin{array}{l}\text { Kotak } \\
\text { pembebanan dan } \\
\text { dudukan benda } \\
\text { penggesek }\end{array}$ & $\begin{array}{l}\text { Untuk penempatan } \\
\text { beban dan juga } \\
\text { sebagai penyagga } \\
\text { benda penggesek. }\end{array}$ \\
\hline 11. & $\begin{array}{l}\text { Benda } \\
\text { penggesek }\end{array}$ & $\begin{array}{l}\text { Benda yang akan } \\
\text { bekerja menggesek } \\
\text { spesimen yang akan } \\
\text { di uji }\end{array}$ \\
\hline 12. & Ragum & $\begin{array}{l}\text { Sebagai penjepit dan } \\
\text { penahan sepesimen } \\
\text { yang akan di uji. }\end{array}$ \\
\hline 13. & Control Panel & $\begin{array}{l}\text { Berfungsi untuk } \\
\text { mengatur dan } \\
\text { mengawasi kerja } \\
\text { alat. }\end{array}$ \\
\hline
\end{tabular}

\section{Hasil dan Pembahasan}

\subsection{Sub bab 1}

Perencanaan motor penggerak

- $\quad$ Daya motor penggerak $(\mathrm{P})=1 / 2 \mathrm{HP}=$ $0,367 \mathrm{KW}=1450 \mathrm{rpm}$

- Putaran motor penggerak $\left(n_{1}\right)=50 \mathrm{~mm}$

- Putaran puli pada poros $\left(n_{2}\right)=350,4 \mathrm{~mm}$

- Jarak sumbu poros $(\mathrm{C})=300 \mathrm{~mm}$ 


$$
\begin{gathered}
\frac{n_{2}}{n_{1}}=\frac{d_{1}}{d_{2}} \\
n_{2}=n_{1} \frac{d_{2}}{d_{1}}=1450 \frac{50}{350,4}=207 \mathrm{rpm}
\end{gathered}
$$

\subsection{Sub bab 2}

Jadi putaran puli pada poros $\left(n_{2}\right)$ adalah $207 \mathrm{rpm}$

Pemilihan sabuk-V

a. Daya rencana $(\mathrm{Pd})$

$\mathrm{Pd}=\mathrm{fc} \times n_{1} \ldots . \mathrm{Kg}$

$=1,4 \times 0,367 \mathrm{Kw}$

$=0,51 \mathrm{KW}$

Dimana $\mathrm{fc}=$ Faktor koreksi $(1,4)$ di peroleh dari tabel faktor koreksi (Sularso, 2004)

$\mathrm{P}=$ Daya motor penggerak

b. Momen rencana $(\mathrm{T})$

$$
\begin{aligned}
& T_{1}=9,74 \times 10^{5}\left(\frac{P d}{n_{1}}\right) \ldots . \mathrm{Kg} . \mathrm{mm} \\
= & 9,74 \times 10^{5} \times\left(\frac{0,51}{1450}\right) \\
= & 342,6 \mathrm{Kg} \cdot \mathrm{mm} \\
& T_{2}=9,74 \times 10^{5}\left(\frac{P d}{n_{2}}\right) \ldots . \mathrm{Kg} . \mathrm{mm} \\
= & 9,74 \times 10^{5} \times\left(\frac{0,51}{207}\right) \\
= & 2399,7 \mathrm{Kg} . \mathrm{mm}
\end{aligned}
$$

c. Bahan Poros S45C-D, $\sigma_{B}=58(\mathrm{Kg} /$ $\mathrm{mm}^{2}$

$s f_{1}=6 \quad s f_{2}=2$

$\tau_{a}=\frac{58}{s f 1 . s f 2} \rightarrow \sigma B=58 \frac{\mathrm{Kg}}{\mathrm{mm}^{2}}$

$=\frac{58}{6 \times 2}$

$=4,83 \frac{\mathrm{Kg}}{\mathrm{mm}^{2}}$

$d s_{1}=\frac{5,1}{4,83} \times K t \times C b \times T_{1}=$

$\left\{\left(\frac{5,1}{4,83}\right) \times 2 \times 2 \times 342,6\right\}^{1 / 3}$

$=11,3 \mathrm{~mm} \rightarrow 12 \mathrm{~mm}$, baik

$d s_{2}=\frac{5,1}{4,38} \times K_{t} \times C_{b} \times T_{2}$

$=\left\{\left(\frac{5,1}{4,38}\right) \times 2 \times 2 \times 2399,7\right\}^{1 / 3}$

$=21,64 \mathrm{~mm} \rightarrow 22 \mathrm{~mm}$, baik

d. Penampang sabuk-V : tipe A

$$
d_{\text {min }}=65 \mathrm{~mm}
$$

$d_{p}=65(\mathrm{~mm}), D_{p}=65 \times 7=$

$455 \mathrm{~mm}$

$$
\begin{gathered}
d_{k}=65+1,8 \times 4,5=73,1(\mathrm{~mm}) \\
D_{p}=455+1,8 \times 4,5=463,1(\mathrm{~mm}) \\
\frac{5}{3} d_{s 1}+10=20,8 \rightarrow d_{B}=30(\mathrm{~mm}) \\
\frac{5}{3} d_{s 2}+10=31 \rightarrow d_{B}=31(\mathrm{~mm})
\end{gathered}
$$

e. Kecepatan linear sabuk-V

$$
\begin{gathered}
v=\frac{\pi \cdot d_{p} \cdot n_{1}}{60 \times 1000} \\
v=\frac{3,14 \times 455 \times 1450}{60 \times 1000}=34.5\left(\frac{\mathrm{m}}{\mathrm{s}}\right)
\end{gathered}
$$

$34,5 \mathrm{~m} / \mathrm{s}<$ kecepatan maksimal $50 \mathrm{~m} / \mathrm{s}$ (baik)

f. $\quad 300-\frac{73,1+463,1}{2}=32 \mathrm{~mm}$, baik

g. Panjang sabuk

$$
\begin{aligned}
L= & 2 . C+\frac{\pi}{2}(d p+D p)+\frac{1}{4 . c}(D p-d p)^{2} \\
& =2 \times 300+\frac{3.14}{2}(50+350,4)+ \\
& \frac{1}{4.300}(350,4-50)^{2} \\
= & 1304 \mathrm{~mm} \rightarrow 1321 \mathrm{~mm}
\end{aligned}
$$

h. Nomor nomimal sabuk-V : No. $52 \mathrm{~L}=$ $1321 \mathrm{~mm}$

i. $\quad h=2 \times 1321-3,14(455+65)=$ 1009,2

$$
C=\frac{1009,2+\sqrt{1009,2^{2}-8(455-65)^{2}}}{8}=
$$

$126,3 \mathrm{~mm}$

j. Sudut kontak

$$
\begin{gathered}
\theta=180^{\circ}-\frac{57(D p-d p)}{C} \\
=180^{\circ}-\frac{57(350,4-50)}{300} \\
=123^{\circ} \rightarrow K_{\theta}=0,82
\end{gathered}
$$

k. $\Delta C_{i}=20 \mathrm{~mm}, \Delta C_{t}=50 \mathrm{~mm}$

1. Tipe A, No 52, $d_{k}=73,1 \mathrm{~mm}, D_{p}=$ $463,1 \mathrm{~mm}$

Lubang poros $18(\mathrm{~mm}), 35(\mathrm{~mm})$ Jarak Sumbu Poros 126,3 $+20 \mathrm{~mm}$

\subsection{Sub bab 3}

Perencanaan beban poros

Diketahui data-data poros

Panjang poros $=180 \mathrm{~mm}$

Bahan poros $\mathrm{S} 45 \mathrm{C}$ dengan kekuatan tarik $\sigma \tau=$ $58 \mathrm{Kg} / \mathrm{mm}^{2}$

Data yang ditransmisikan $\mathrm{P}(\mathrm{Kw})$

$\mathrm{P}=0,5 \mathrm{HP}=0,373 \mathrm{Kw}$

Putaran poros $1, n_{1}=1450 \mathrm{rpm}$

Putaran poros $2, n_{2}=207 \mathrm{rpm}$ 
Faktor koreksi, $\mathrm{fe}=1,2 \mathrm{Pd} 0,373.1,2=0,45$

Momen rencana $T_{1}(\mathrm{Kg} / \mathrm{mm})$ (Sularso, 2004)

Dimana:

- $T_{1} \quad=$ Momen punter

- $P d=$ Faktor koreksi

- $n_{1} \quad=$ Putaran motor

$=9,74 \cdot 10^{5} \frac{P d}{n_{1}}$

$=9,74.10^{5} \frac{0,51}{1450}$

$T_{1}=342,6 \mathrm{~kg} . \mathrm{mm}$

Momen rencana $T_{2}(\mathrm{Kg} / \mathrm{mm})$

(Sularso, 2004)

Dimana : $T_{2}=$ momen

$P_{d} \quad=$ faktor koreksi

$n_{2} \quad=$ putaran piringan

$T_{2} \quad=9,74.10^{5} \frac{0,51}{207}$

$T_{2} \quad=2399,7 \mathrm{Kg} . \mathrm{mm}$

Gaya - gaya pebebanan pada poros

a. Tegangan geser yang diijinkan

$$
\tau \alpha=
$$

Dimana :

$\sigma \tau=$ Tegangan tarik bahan $\mathrm{S} 45 \mathrm{C}$ $\left(58 \frac{\mathrm{kg}}{\mathrm{mm}}^{2}\right)$

$S f_{1} \quad=$ faktor keamanan untuk bahan $(6,0)$ (Sularso, 2004)

$S f_{2} \quad=$ faktor keamanan untuk

konsentrasi tegangan alur pasak dan

kekerasan dan kekerasan $(2,0)$ (Sularso, 2004)

$\sigma \alpha=58 /(6,0 \times 2,0)=4,83 \mathrm{~kg} / \mathrm{mm}^{2}$

b. Diameter poros I

$d s_{1}=\left[K_{t} \cdot C_{b} \cdot T_{1}\right]^{1 / 3}$

Dimana :

$\tau \alpha=$ tegangan geser $\left(4,83 \frac{\mathrm{Kg}^{2}}{\mathrm{~mm}}\right)$

$K_{t}=$ faktor koreksi karena puntiran dan

tumbukan ringan $(3,0)$ (Sularso, 2004)

$C_{b}=$ faktor koreksi karena beban dan tumbukan ringan $(2,3)$ (Sularso, 2004)

$T_{1}=$ momen puntir $(342,6 \mathrm{~kg} / \mathrm{mm})$

$T_{2}=$ momen puntir $(2399,7 \mathrm{~kg} / \mathrm{mm})$

Sehingga, $d s_{1}=[2,3.3,0.342,6]^{1 / 3}$

$=13 \mathrm{~mm}$ c. Diameter poros II

$d s_{2}=\left[K_{t} \cdot C_{b} \cdot T_{1}\right]^{1 / 3}$

Dimana :

$$
d s_{1}=[2,3.3,0.2399,7]^{1 / 3}
$$

$=25 \mathrm{~mm}$

d. Berat poros

$W_{p}=: d s^{2} \cdot \tau \cdot \gamma$

Dimana :

$d=$ diameter poros yang direncanakan $=$

$25 \mathrm{~mm}$

$\tau=$ panjang poros $=180 \mathrm{~mm}$

$\gamma=$ berat jenis baja karbon $=0,00785$

$\mathrm{Kg} / \mathrm{cm}^{2}$

Maka :

$W_{p}=\cdot 2,5^{2} \cdot 18 \cdot 0.00785$

$$
=0,883 \mathrm{Kg}
$$

\subsection{Sub bab 4}

Menetukan diameter puli penggerak (Sularso, 2004)

Dimana :

$n_{1}=$ putaran motor

$n_{2}=n_{3}=$ Putaran piringan

$D_{1}=$ diameter puli

$D_{2}=$ diameter puli penggerak

$n_{2} \frac{n_{1} \cdot D_{1}}{D_{2}}$

$207=\frac{1450.50}{207}=350,24 \mathrm{~mm}$

\subsection{Sub bab 5}

Menghitung keceapatan linier speed connecting rod

Dimana:

$\mathrm{D}=$ diameter piringan $=90 \mathrm{~mm}$

$n=$ putaran piringan $=207 \mathrm{rpm}$

a. Kecepatan sudut dari piringan ( $\mathrm{rad} / \mathrm{s})$ $\omega=2 . \pi \cdot n=2 \times 3,14 \times\left(\frac{207}{60}\right)=$ $21,66(\mathrm{rad} / \mathrm{s})$

b. Kecepatan connecting $\operatorname{rod}(\mathrm{mm} / \mathrm{s})$ 
$v=R . \omega=45 \mathrm{~mm} \times 21,66 \frac{\mathrm{rad}}{\mathrm{s}}=974,7 \mathrm{~mm} / \mathrm{s}$

\section{6. $S u b b a b 6$}

\section{Spesifikasi Alat Uji Keausan}

Spesifikasi dari Alat Uji Keausan (Tribometer) Dengan Penggerak Motor Tipe XD - 135 dapat dilihat pada tabel dibawah ini.

Tabel 4.1. Spesifikasi alat uji keausan

\begin{tabular}{|l|l|}
\hline Rotation speed & $207 \mathrm{rpm}$ \\
\hline Linier speed & $974,7 \mathrm{~mm} / \mathrm{s}$ \\
\hline $\begin{array}{l}\text { Maximum } \\
\text { normal load }\end{array}$ & $98 \mathrm{~N}$ \\
\hline Normal force & $49 \mathrm{~N}$ \\
\hline Stroke lenght & $70 \mathrm{~mm}$ \\
\hline
\end{tabular}

\section{7. $S u b b a b 7$}

Hasil Rancangan Konstruksi

Perancangan konstruksi tribometer dengan penggerak motor tipe XD - 135 dimaksudakan untuk pengujian laju keausan gesek yang terjadi pada logam yang saling bergesekan

Adapun beberapa hal yang menjadi sasaran dalam pengujian laju keausan pada benda logam yang umum terjadi keusan gesek seperti di part kendaran dan benda logam yang saling bergesekan satu sama lain yaitu: perancangan rangka, rancangan penggerak, rancangan benda penggesek, dan dudukan benda uji yang kan digesek. Pembuatan desain alat uji menggunakan aplikasi CAD.

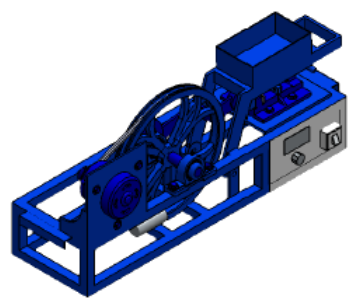

Gambar 4.1. Hasil desain alat uji keusan

Perancangan Rangka

Dalam perancangan rangaka pada tribometer dengan penggerak motor tipe XD - 135 di desain simpel, kokoh dan minimalis, dengan tujuan agar tidak susah dipindahkan dari suatu tempat ketempat yang lain, tahan terhadap getaran yang kuat, dan tidak membutuhkan tempat yang luas.

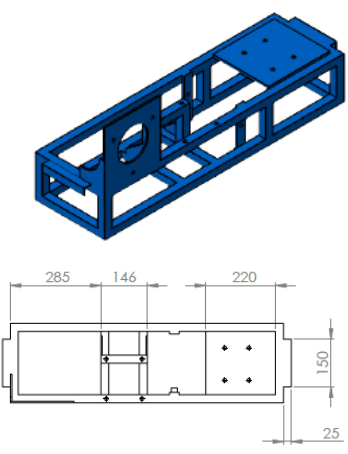

Gambar 4.2. Desain rangka alat uji keausan

Tabel 4.2. Perhitungan selisih dan presentase kesalahan DT

\begin{tabular}{|c|c|c|}
\hline No & Keterangan & Perhitungan \\
\hline 1 & $\begin{array}{l}\text { Total dimensi } \\
\text { luar }\left(D_{\text {luar }}\right)\end{array}$ & $\begin{array}{l}=P_{x} \times L_{x} \times T_{x} \\
=860 \times 250 \times \\
150 \\
=32.250 \mathrm{~mm}^{3} \\
=32,25 \mathrm{~cm}^{3} \\
=0.3225 \mathrm{~m}^{3}\end{array}$ \\
\hline 2 & $\begin{array}{l}\text { Total dimensi } \\
\text { dalam }\left(D_{\text {dalam }}\right)\end{array}$ & $\begin{array}{l}=P \mathrm{~g} \times L \mathrm{~g} \times T_{\mathrm{g}} \\
=810 \times 200 \times \\
100 \\
=16,20 \mathrm{~mm}^{3} \\
=0,162 \mathrm{~m}^{3}\end{array}$ \\
\hline 3 & $\begin{array}{l}\text { Total selisih } \\
\text { dimensi }(\Delta D)\end{array}$ & $\begin{array}{l}=D_{L}-D_{d} \\
=0,3225 \mathrm{~m}^{3}- \\
0,162 \mathrm{~m}^{3} \\
=0,1605 \mathrm{~m}^{3}\end{array}$ \\
\hline
\end{tabular}

Rancangan Motor penggerak Motor yang dipilih untuk sumber penggerak iyalah motor kapasitor 1 phase dengan spesifikasi seperti berikut.

Spesifikasi motor :

- $\quad$ Type motor XD-135

- $\quad$ Model kaki 3, jarak kaki $15 \mathrm{~cm}$ x $15 \mathrm{~cm}$ x $15 \mathrm{~cm}$

- Daiameter As $10 \mathrm{~mm}$, panjang As $5,1 \mathrm{~cm}$

- Tinggi bodi motor $9,5 \mathrm{~cm}$.

- Diameter bodi motor $11,4 \mathrm{~cm}$

- Tebal lilitan hitam (palat besi lilitan kawat) $3,3 \mathrm{~cm}$.

- $220 \mathrm{v}-50 \mathrm{~Hz}$

- $135 \mathrm{~W} 1,30 \mathrm{~A} 4 \mathrm{P}$

- $10 \mu F / 450 \mathrm{~V}$ Class B 
- $\quad$ Fuse protection $135^{\circ} \mathrm{C}$

- $1450 \mathrm{rpm}$
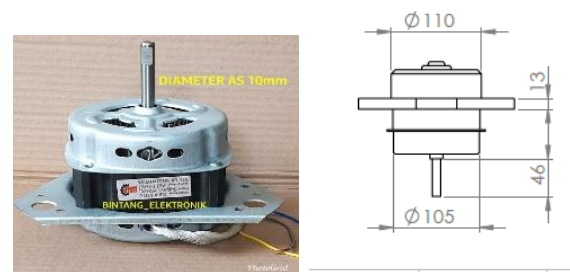

Gambar 4.3. Motor kapasitor

Mengapa dipilih motor dengan spesifikasi sperti diatas karena memang spesifiksi diatas yang akan dibutuhkan untuk sumber penggerak, gampang di dapatkan karena banyak dijual dipasaran dan dari segi haraga tidak terlalu mahal.

Rancangan Penghubung Gerak

Sistim penghubung gerak yang digunakan yaitu pulley dan sabuk - V yang terhubung ke poros dan crankshaft diteruskan oleh connecting rod ke benda penggesek. Sistim ini dipilih agar tidak memerlukan perawatan yang khusus sehinngga tidak membutuhkan biaya perawatan yang banyak dan juga sistim ini lebih simpel serta mudah untuk diterapkan pada alat uji ini.
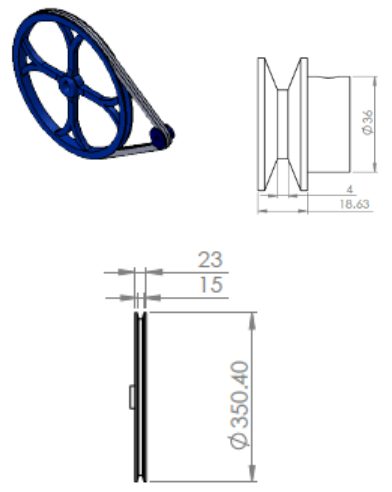

Gambar 4.4. Desain Puli dan sabuk-V
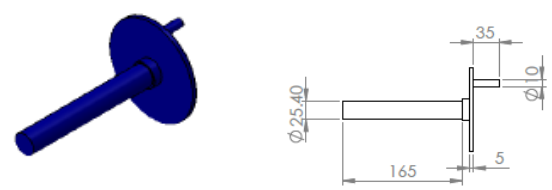

Gambar 4.5. Desain poros dan disc
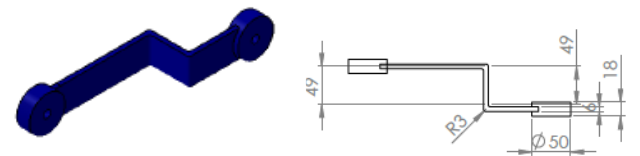

Gambar 4.6. Desain connecting rod

Rancangan Dudukan Pembebanan

Dudukan pembebanan bisa naik turun tujuannya adalah supaya bisa menekan saat diberi

pembebanan pada kotak pembebanan yang sudah disediakan.

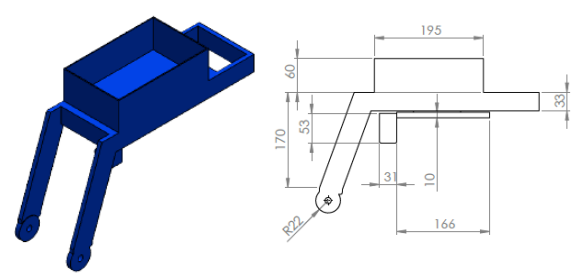

Gambar 4.7. Desain dudukan Benda Penggesek

Rancangan Benda Penggesek

Untuk benda penggesek yang akan bergerak linear maka dipilih sistim double bushing agar bisa sebagai penyeimbang gerak linear pada benda penggesek dan juga alat ini (bushing) banyak dijual di toko-toko Teknik, untuk pembuatannya juga tidak susah.
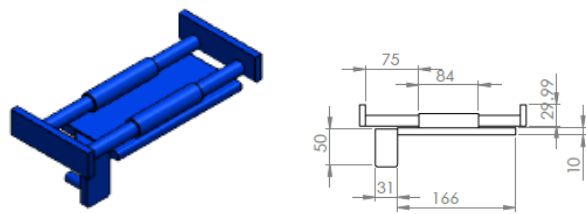

Gambar 4.8. Desain benda Penggesek

Rancangan dudukan benda uji

Dudukan benda uji (specimen) yaitu ragum bor ukuran 3", mengapa dipilih ragum bor 3" karna untuk menjepit benda uji (specimen) 
sangat baik dan juga tidak memrlukan tempat yang luas.
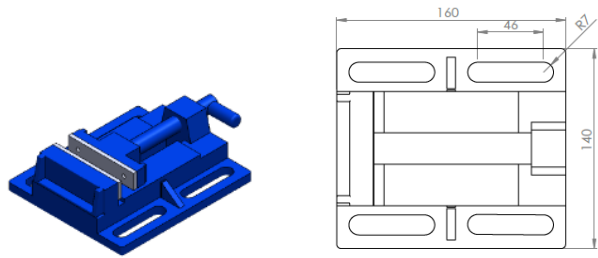

Gambar 4.9. Desain ragum

\subsection{Sub $b a b 8$}

Cara Penggunaan Alat Uji Tribometer

Cara penggunaan alat uji tribometer sangatlah mudah dengan cara menghubungkan steker ke arus listrik lalu tekan on pada saklar lalu motor listrik akan menyala dan menggerakan pulley dan belt diteruskan ke cranksafht yang terhubung ke connecting rod yang akan menghasilkan gerakan linear pada benda penggesek yang akan menggesek benda uji.

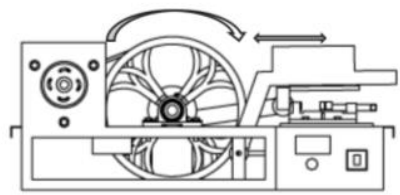

Gambar 4.10. Prinsip kerja alat uji keusan

Dari gambar 4.10. dapat terlihat prinsip kerja , dimana saat motor berputar maka puli dan sabuk-v akan menghatarkan putaran ke poros yang terhubung ke crankshaft, gerakan melingkar dari crankshaft dirubah oleh connecting rod menjadi gerak maju-mundur (linear) pada benda penggesek.

\subsection{Sub bab 9}

\section{Pemilihan Bahan Rangka}

Motor listrik sebagai sumber penggerak yang terhubung ke pulley dan belt untuk mentrasmisikan daya dari satu poros ke poros yang terhubung crankshaft dan diteruskan oleh connecting rod ke benda penggesek sudah tentu menyebabkan fenomena getar yang sangat kuat.

Maka dipilihlah besi hollow yang berukuran $25 \times 25 \mathrm{~mm}$ dengan tebal $1,2 \mathrm{~mm}$ dengan tujun untuk meredam getaran yang terjadi.

\subsection{Sub bab 10}

Proses Pembuatan Dan Perakitan Alat Uji Keausan

Setelah model desain selesai dibuat maka selanjutnya adalah proses pembuatan alat . proses pembuatan dimualai dengan menyediakan peralatan dan bahan yang dipergunakan dalam pembuatan alat uji keausan. Setelah semua semua peralatan tersedia maka langkah selanjutnya melakukan pengukuran dan pemotogan bahan untuk melancarkan penyambungan.

Langakah pertama yang perlu dilakukan dalam pembuatan alat uji keausan adalah sebagai berikut.

1. Dikarenakan keterbatasan mesin produksi maka pada part tertentu dibeli sesuai ukuruan seperti, dudukan motor, poros puli penggerak, disc, connecting rod, dan rangka dudukan pembebanan, part tersbut menggunakan bahan besi padu dan besi plat tebal.

2. Pemotongan besi hollow sesuai dengan ukuran, kemudian diarakit dengan cara disambung dengan menggunakan las listrik.

3. Pengeboran lubang baut dan as yang akan diperlukan setiap part alat uji keusan.

4. Pengelasan as pada disc dan as pada benda penggesek.

5. Pengelasan benda penggesek pada bushing.

6. Pengelasan kotak pembebanan dan dudukan benda penggesek.

7. Pemasangan part dengan baut dengan urutan motor, puli motor, pillow blocks bearing, connecting rod, as dudukan pembebanan, dan ragum.

8. Pemasangan sabuk-v pada puli motor dan puli penggerak.

9. Pemasangan poros puli penggerak dan pengelasan disc pada poros.

10. Pemasangan connecting rod pada disc dan benda penggesek kemudian dikunci dengan baut.

11. Pemotongan dan pemasangan plat untuk control panel.

12. Alat uji di cat sesuai warna yang sudah ditentukan. 
13. Pemasangan part kelistirikan sperti kabel-kabel, kapasitor, dimmer, sensor rpm dan staker.
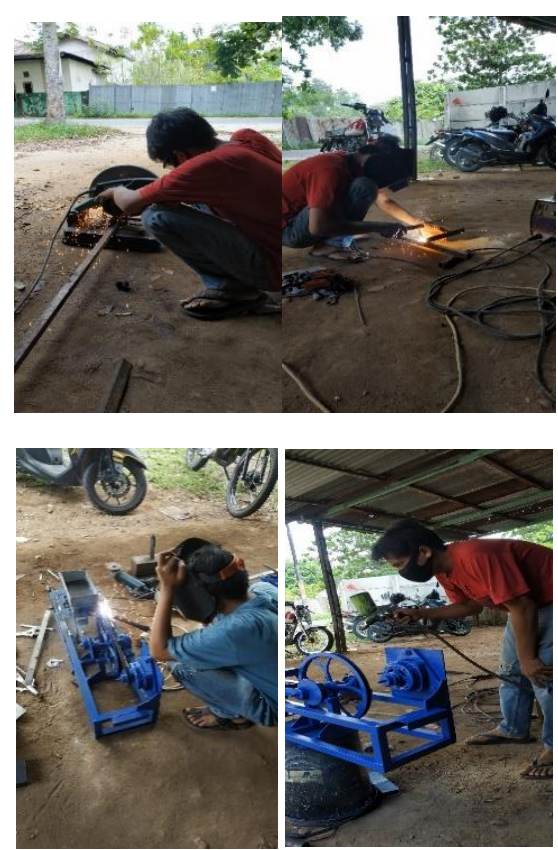

Gambar 4.11. Proses fabrikasi alat uji keausan

\section{Simpulan}

Bersarkan penelitian tentang rancang bangun alat uji tribometer dengan penggerak motor tipe XD - 135 didapat kesimpulan sebagai berikut :

1. Telah dirancang alat uji tribometer dengan penggerak motor tipe $\mathrm{XD}$ 135 dengan material yang digunakan dalam pembuatan rangka ialah besi holo $25 \times 25 \mathrm{~mm}$ dengan tebal $1,2 \mathrm{~mm}$, dengan menggunakan penggerak motor listrik menngerakkan pulley dan belt diteruskan ke crankshaft yang terhubung ke connecting rod yang akan menghasilkan gerakan linear pada benda penggesek yang akan menggesek benda uji.

2. Setelah dilakukan uji coba maka terlihat alat uji keausan (tribometer) dengan penggerak motor tipe XD-135 ini, bekerja dengan baik.

\section{Daftar Pustaka}

Ady Setiawan1, J. jamari2, Marwan Effendy3, Dimas Ardiansyah4. 2018. "Rancang Bangun Alat Uji Keausan Berbasis Sistem
Kontak Disc-On-Disc” Universitas Muhammadiyah Surakarta. Surakarta.

Kun Mukhammad Wafda. 2015. "Rancang Bangun Struktur Dan Mekanisme Pembebanan Tribometer Tipe Pin-On-Plate Gerakan Reciprocating Dengan Penggerak Electropneumatic". Institut Tenologi Sepuluh Nopember. Surabaya.

Taufik Hidayatullah. 2018. "Rancang Bangun Alat Uji Koefisien Gesek Tipe Pin On Disk Menggunakan Metode Pahl Dan Beitz". Universitas Lampung. Bandar Lampung.

Triono, A. (2013). pengaruh kecepatan relatif permukaan gesek dan 
temperatur. Agus Triono, Jurnal ROTOR, Volume 6 Nomor 1, Januari 2013, 6 .

[10] Sularso. (2004). Dasar Perancangan Dan Pemilihan Elemen
Mesin. Bandung, Indonesia dan Tokyo Jepang: PT. Pradayana Paramita Jalan Bunga No. 8-8A Jakarta 13140. 